\title{
A Mendelian polymorphism underlying quantitative variations of goat $\alpha_{s 1}$-casein
}

\author{
F. GROSCLAUDE, Marie-Françoise MAHÉ, Ghislaine BRIGNON *, \\ Liliana DI STASIO ${ }^{* *}$ and R. JEUNET *** \\ I.N.R.A., Laboratoire de Génétique Biochimique, Centre de Jouy-en-Josas, \\ F 78350 Jouy-en-Josas \\ * I.N.R.A., Laboratoire de Biochimie et Technologie Laitières, Centre de Jouy-en-Josas, \\ F 78350 Jouy-en-Josas \\ ** Osservatorio di Genetica Animale, Via Pastrengo, 28, 10128 Torino, Italie \\ *** I.N.R.A., Station Expérimentale Laitière, B.P. 94, F 39800 Poligny
}

\begin{abstract}
Summary
Using SDS-polyacrylamide gel electrophoresis and rocket immunoelectrophoresis, 3 new alleles, designated $\alpha_{\mathrm{s} 1}-\mathrm{Cn}^{\mathrm{B}^{-}}, \alpha_{\mathrm{s} 1} \mathrm{Cn}^{\mathrm{F}}$ and $\alpha_{\mathrm{s} 1}{ }^{-} \mathrm{Cn}^{\mathrm{O}}$, were identified at the goat $\alpha_{\mathrm{s} 1}-\mathrm{Cn}$ locus, in addition to alleles $\alpha_{\mathrm{s} 1}-\mathrm{Cn}^{\mathrm{A}}, \alpha_{\mathrm{s} 1}-\mathrm{Cn}^{\mathrm{B}}$ and $\alpha_{\mathrm{s} 1}-\mathrm{Cn}^{\mathrm{C}}$ previously reported by Boulanger et al. (1984). Alleles $\alpha_{\mathrm{s} 1}{ }^{-}$ $\mathrm{Cn}^{\mathrm{A}}, \alpha_{\mathrm{s} 1}-\mathrm{Cn}^{\mathrm{B}}$ and $\alpha_{\mathrm{s} 1}-\mathrm{Cn}^{\mathrm{C}}$ are associated with a high content of $\alpha_{\mathrm{s} 1}$-casein (approximate mean contribution of each allele being $3.6 \mathrm{~g} / \mathrm{l})$ compared to $\alpha_{\mathrm{s}}-\mathrm{Cn}^{\mathrm{F}}$ with a low content $(0.6 \mathrm{~g} / \mathrm{l})$ and $\alpha_{\mathrm{sl}}$ $\mathrm{Cn}^{\mathrm{B}^{-}}$with an intermediate content $(1.6 \mathrm{~g} / 1) ; \alpha_{\mathrm{s} 1}-\mathrm{Cn}^{\mathrm{O}}$ appears to be a true null allele. In a sample of 213 Alpine females from 49 flocks in West Central France, the frequencies of the 6 alleles were : $\alpha_{\mathrm{s} 1}-\mathrm{Cn}^{\mathrm{A}}=0.14 ; \alpha_{\mathrm{s} 1}-\mathrm{Cn}^{\mathrm{B}}=0.05 ; \alpha_{\mathrm{s} 1}-\mathrm{Cn}^{\mathrm{C}}=0.01 ; \alpha_{\mathrm{s} 1}-\mathrm{Cn}^{\mathrm{B}-}=0.34 ; \alpha_{\mathrm{s} 1}-\mathrm{Cn}^{\mathrm{F}}=0.41 ;$ and $\alpha_{s 1}-\mathrm{Cn}^{\mathrm{O}}=0.05$. In a sample of 159 Saanen females from 52 flocks of the same region, the frequencies were : $\alpha_{\mathrm{s} 1}-\mathrm{Cn}^{\mathrm{A}}=0.07 ; \quad \alpha_{\mathrm{s} 1}-\mathrm{Cn}^{\mathrm{B}}=0.06 ; \quad \alpha_{\mathrm{s} 1}-\mathrm{Cn}^{\mathrm{C}}=0 ; \quad \alpha_{\mathrm{si}}-\mathrm{Cn}^{\mathrm{B}^{-}}=0.41 ; \quad \alpha_{\mathrm{s} 1}{ }^{-}$ $\mathrm{Cn}^{\mathrm{F}}=0.43 ; \alpha_{\mathrm{s} 1}-\mathrm{Cn}^{\mathrm{O}}=0.03$. Additional data confirm that loci $\alpha_{\mathrm{s} 1}-\mathrm{Cn}$ and $\alpha_{\mathrm{s} 2}-\mathrm{Cn}$ are closely linked.

Preliminary investigations indicated a significant superiority in casein content of milks from goats possessing the allele $\alpha_{\mathrm{s} 1}-\mathrm{Cn}^{\mathrm{A}}$, as compared to that of milks from goats of genotypes $\alpha_{\mathrm{s} 1}-\mathrm{Cn}^{\mathrm{F}} /$ $\alpha_{\mathrm{s} 1}-\mathrm{Cn}^{\mathrm{F}}$ and $\alpha_{\mathrm{s} 1}-\mathrm{Cn}^{\mathrm{B}} / \alpha_{\mathrm{s} 1}-\mathrm{Cn}^{\mathrm{F}}$ and, in a large herd $(\mathrm{N}=251)$, a strong correlation was observed between the $\alpha_{\mathrm{s} 1}$-casein content and the rennet-casein content of milk $(\mathrm{r}=0.68 ; \mathrm{b}=0.64)$.
\end{abstract} variations.

Key words : Goat, $\alpha_{\mathrm{s} 1}$-casein, $\alpha_{\mathrm{s} 2}$-casein, polymorphism, null type, genetic linkage, quantitative

\section{Résumé}

Un polymorphisme mendélien sous-jacent aux variations quantitatives de la caséine $\alpha_{\mathrm{s} 1}$ caprine

A l'aide d'électrophorèses en gel de polyacrylamide SDS et d'immuno-électrophorèses « rocket », 3 allèles, appelés $\alpha_{\mathrm{s} 1}-\mathrm{Cn}^{\mathrm{B}}, \alpha_{\mathrm{si}}-\mathrm{Cn}^{\mathrm{F}}$ et $\alpha_{\mathrm{s} 1}-\mathrm{Cn}^{\mathrm{O}}$, ont été identifiées au locus $\alpha_{\mathrm{s} 1}-\mathrm{Cn}$ de la chèvre, en plus des allèles $\alpha_{\mathrm{si}}-\mathrm{Cn}^{\mathrm{A}}, \alpha_{\mathrm{si}}-\mathrm{Cn}^{\mathrm{B}}$ et $\alpha_{\mathrm{si}}-\mathrm{Cn}^{\mathrm{C}}$ déjà détectés par Boulanger et al. (1984). Les allèles $\alpha_{\mathrm{s} 1}-\mathrm{Cn}^{\mathrm{A}}, \alpha_{\mathrm{s} 1}-\mathrm{Cn}^{\mathrm{B}}$ et $\alpha_{\mathrm{s} 1}-\mathrm{Cn}^{\mathrm{C}}$ sont associés à un taux élevé de caséine $\alpha_{\mathrm{s} 1}$ (contribution approximative de chaque allèle : $3,6 \mathrm{~g} / \mathrm{l})$, l'allèle $\alpha_{\mathrm{s} 1}{ }^{-} \mathrm{Cn}^{\mathrm{F}}$ a un taux faible $(0,6 \mathrm{~g} / \mathrm{l})$ et l'allèle $\alpha_{\mathrm{s} 1^{-}}$ 
$\mathrm{Cn}^{\mathrm{B}}$ a un taux intermédiaire (1,6 g/l). Dans un échantillon de 213 femelles Alpine provenant de 49 troupeaux du centre-ouest de la France, les fréquences des 6 allèles actuellement identifiés étaient les suivantes: $\alpha_{\mathrm{s} 1}-\mathrm{Cn}^{\mathrm{A}}=0,14 ; \alpha_{\mathrm{s1}}-\mathrm{Cn}^{\mathrm{B}}=0,05 ; \alpha_{\mathrm{s} 1}-\mathrm{Cn}^{\mathrm{C}}=0,01 ; \alpha_{\mathrm{s} 1}-\mathrm{Cn}^{\mathrm{B}^{-}}=0,34 ; \alpha_{\mathrm{si}}$ $\mathrm{Cn}^{\mathrm{F}}=0,41$ et $\alpha_{\mathrm{s} 1}-\mathrm{Cn}^{\mathrm{O}}=0,05$. Dans un échantillon de 159 femelles Saanen provenant de 52 troupeaux de la même région, les fréquences étaient: $\alpha_{\mathrm{s1}}-\mathrm{Cn}^{\mathrm{A}}=0,07 ; \alpha_{\mathrm{s} 1} \mathrm{Cn}^{\mathrm{B}}=0,06 ; \alpha_{\mathrm{s} 1^{-}}$ $\mathrm{Cn}^{\mathrm{C}}=0 ; \alpha_{\mathrm{s} 1}-\mathrm{Cn}^{\mathrm{B}^{-}}=0,41 ; \alpha_{\mathrm{s} 1}-\mathrm{Cn}^{\mathrm{F}}=0,43 ; \alpha_{\mathrm{s} 1}-\mathrm{Cn}^{\mathrm{O}}=0,03$. Des données supplémentaires confirment que les loci $\alpha_{\mathrm{s} 1}-\mathrm{Cn}$ et $\alpha_{\mathrm{s} 2}-\mathrm{Cn}$ sont étroitement liés.

Des investigations préliminaires révèlent que le taux de caséine des laits des chèvres possédant l'allèle $\alpha_{\mathrm{s} 1}{ }^{-} \mathrm{Cn}^{\mathrm{A}}$ est significativement supérieur à celui des laits des chèvres de génotype $\alpha_{\mathrm{s} 1}{ }^{-} \mathrm{Cn}^{\mathrm{F}} / \alpha_{\mathrm{s} 1}$ $\mathrm{Cn}^{\mathrm{F}}$ ou $\alpha_{\mathrm{s} 1}-\mathrm{Cn}^{\mathrm{B}^{-}} / \alpha_{\mathrm{s} 1}-\mathrm{Cn} \mathrm{n}^{\mathrm{F}}$; par ailleurs, dans un grand troupeau $(\mathrm{N}=251)$, une forte corrélation a été observée entre le taux de caséine $\alpha_{\mathrm{s} 1}$ et le taux de matières azotées coagulables $(r=0,68$; $\mathrm{b}=0,64)$.

Mots clés: Chèvre, caséine $\alpha_{\mathrm{s} 1}$, caséine $\alpha_{\mathrm{s} 2}$, polymorphisme, type nul, liaison génétique, variations quantitatives.

\section{Introduction}

BOUlANGER et al. (1984) demonstrated by starch gel electrophoresis that goat $\alpha_{\mathrm{st}}$ casein exhibited a rather complex polymorphism, which appeared to result from the combination of 2 forms of heterogeneity, both being controlled by locus $\alpha_{s 1}-\mathrm{Cn}$. These were a classical electrophoretic polymorphism with 3 variants, $\alpha_{\mathrm{sl}}-\mathrm{Cn} \mathrm{A}, \mathrm{B}$ and $\mathrm{C}$, and a quantitative variation, apparently only associated with the $\alpha_{s 1}-\mathrm{Cn} B$ variant. While it was considered that the inheritance of $\alpha_{\mathrm{s1}}-\mathrm{Cn} \mathrm{A}$ and $\alpha_{\mathrm{s1}}-\mathrm{Cn} \mathrm{C}$ had been established, an analysis of the genetic basis for the quantitative variations associated with variant $\alpha_{\mathrm{sl}}-\mathrm{Cn}$ $\mathrm{B}$ remained to be done.

The present paper provides additional results on the genetic control of goat $\alpha_{s 1}$ casein polymorphism and on the associated quantitative variations.

\section{Materials and methods}

\section{A. Origin and preparation of milk samples}

Individual milk samples were collected at one milking from goats born of artificial insemination and their mothers. A total of 888 samples, representing 476 dam-daughter pairs and subdivisible into 24 sire families were collected at the end of June 1985 from 101 private farms located in West Central départements of France (mainly Deux-Sèvres and Vienne, but also Loir-et-Cher, Maine-et-Loire, Charente and Haute-Vienne). The numbers of dam-daughter pairs per sire varied from 5 to 64 , with only 10 sires having more than 20 pairs. For the quantification of the caseins, individual samples were collected again in August 1985 from animals (112 samples from 43 farms) chosen according to their genotype.

To estimate the relationship between the $\alpha_{\mathrm{s} 1}$-casein contents of milks and their protein compositions, individual samples were obtained from the "Station de Testage Caprin » near Moissac (48110 Sainte-Croix Vallée Française) during April, 1986. 
To all the samples (15 to $20 \mathrm{ml}$ ) were added 2-3 drops of a solution of potassium dichromate $(10 \mathrm{~g} / \mathrm{l}), 2-3$ drops of a $10 \mathrm{mM}$ solution of Phenylmethylsulfonidefluoride (Serva) in isopropanol, and 2-3 drops of a $10 \mathrm{mM}$ aqueous solution of $\epsilon$-amino-n-caproïc acid (Serva). The preserved samples were stored at $-20^{\circ} \mathrm{C}$ pending chemical analysis.

The biochemical analysis of a $F \alpha_{s 1}$-casein type was carried out on a fresh individual milk sample provided by the "Domaine Expérimental de Brouessy » (I.N.R.A., 78470 Magny-les-Hameaux).

\section{B. Electrophoresis techniques}

Acid starch gel electrophoresis (SGE) was carried out as described by BoulangER et al. (1984).

SDS-Polyacrylamide gel electrophoresis (SDS-PAGE) was performed on LKB glass plates (size of the gel : $18 \times 15 \times 0.15 \mathrm{~cm}$ ) using a LKB 2117 Multiphor apparatus under conditions derived from those described by LAEMmLi (1970). Gels containing 3 p. 100 (stacking gel) and 14 p. 100 (separation gel) acrylamide were prepared from a stock solution of 30 p. 100 by weight of acrylamide and 0.8 p. 100 by weight of bisacrylamide (Serva). The final concentrations in the separation gels were as follows: $0.39 \mathrm{M}$ tris-HCl (Prolabo), pH 8.9 and 0.1 p. 100 SDS (Serva). The gels were polymerized by the addition of $0.04 \mathrm{p} .100$ by volume of tetramethylethylenediamine (TEMED) and $2.5 \mathrm{p} .100$ by volume of a $10 \mathrm{p} .100$ by weight solution of ammonium persulfate. The stacking gels (approximately $4 \mathrm{~cm}$ ) contained $0.06 \mathrm{M}$ tris- $\mathrm{HCl}, \mathrm{pH} 6.8$, and 0.2 p. 100 SDS ; they were polymerized by addition of 0.2 p. 100 TEMED and 6 p. 100 of ammonium persulfate solution. The electrode buffer contained $0.049 \mathrm{M}$ trizma base (Sigma), $0.38 \mathrm{M}$ glycine (Prolabo) and $0.1 \mathrm{p} .100 \mathrm{SDS}$. The denaturing solution for diluting milk samples was made of $12.5 \mathrm{ml}$ of the tris solution, $\mathrm{pH} 6.8$, $10 \mathrm{ml}$ glycerol, $2.3 \mathrm{~g}$ SDS, $125 \mathrm{mM}$ dithiothreitol (Merck), $0.1 \mathrm{ml}$ of a $1 \mathrm{p} .100$ solution of Coomassie blue $\mathrm{G}$ (Serva) adjusted to $100 \mathrm{ml}$ with distilled water. Samples of milk $(4 \mu \mathrm{l})$ were diluted with the denaturing solution $(17 \mu \mathrm{l})$ followed by addition of $2 \mu \mathrm{l}$ of $\beta$-mercaptoethanol (Prolabo) and boiling for $5 \mathrm{~min}$ in a water-bath.

Electrophoresis (8 samples per plate) was carried out with a current of $180 \mathrm{~V}$ and approximately $65 \mathrm{~mA}$ per plate for 4 hours at $15^{\circ} \mathrm{C}$. The gels were stained for $2-3 \mathrm{~h}$ at room temperature with a 0.3 p. 100 by weight Coomassie brilliant blue $G$ solution made up in 50 p. 100 methanol and 10 p. 100 acetic acid (Prolabo). The gels were destained by repeated washing for $16 \mathrm{~h}$ in a 30 p. 100 methanol, 7.4 p. 100 acetic acid, 10 p. 100 glycerol solution.

\section{Preparation of antibodies specific for individual caseins}

$\beta$-casein was isolated by the precipitation of $\alpha_{\mathrm{s} 1^{-}}, \alpha_{\mathrm{s} 2^{-}}$and $\mathrm{k}$-caseins in $3.3 \mathrm{M}$ urea at pH 4.7 (ThOMPSON \& KIDDY, 1964) and $\alpha_{\mathrm{s} 1}$-casein was then separated by ethanol precipitation of $\alpha_{\mathrm{s} 2^{-}}$and $\kappa$-caseins (ZITTLE \& CUSTER, 1963). The 4 caseins were purified from the above fractions by DEAE-Cellulose chromatography (MERCIER et al., 1968). Their purities were assessed by electrophoresis of high concentrations of proteins in acid and alkaline SGE and SDS-PAGE. 
Antibodies were produced by the immunizations of rabbits with solutions of $0.5 \mathrm{mg}$ casein per $\mathrm{ml}$ of a pH 7.0 buffer $\left(0.1 \mathrm{M} \mathrm{KH}_{2} \mathrm{PO}_{4}, 0.13 \mathrm{M} \mathrm{NaCl}, 2 \mathrm{mM} \mathrm{KCl}\right)$. Rabbits were injected subcutaneously, 15 days apart, at 20 points on both sides of the vertebral column, with 2 doses of $200 \mu$ l casein solution mixed with $200 \mu$ l complete Freund adjuvant. Fifteen days later, a 3rd dose was injected intramuscularly. Rabbits were bled 8-10 days later from the ear arteries.

The specificities of the antibodies were assessed by the double diffusion technique of OUCHTERLONY (1967) and immunoelectrophoresis (Grabar \& Williams, 1953).

\section{Electroblotting of $\alpha_{\mathrm{s} 1}$-casein}

The caseins were transferred from a SDS-PAGE gel onto a nitrocellulose membrane (Biorad, 162-0115) in a Transphor unit, model TE 50 (Haefer scientific Instruments, Bioblock) using a pH 8.3 buffer containing $25 \mathrm{mM}$ tris- $\mathrm{HCl}, 150 \mathrm{mM}$ glycine and 5 p. $100 \operatorname{SDS}(\mathrm{w} / \mathrm{v})$, under a current of 1.2-1.5 A, for $2 \mathrm{~h}$ at $4{ }^{\circ} \mathrm{C}$ (TowBIN et al., 1979). After transfer, the membrane was immersed overnight in a phosphate-saline buffer pH $7.0\left(10 \mathrm{mM} \mathrm{NaH} \mathrm{PO}_{4}, 0.15 \mathrm{M} \mathrm{NaCl}, 0.1\right.$ p. 100 Tween 20) containing 5 p. $100(\mathrm{w} / \mathrm{v})$ BSA (Sigma), and then washed 2-3 times for $1 / 4 \mathrm{~h}$ in the phosphate saline buffer. For fixation of the antibody, the membrane was incubated for $3 \mathrm{~h}$ at $37^{\circ} \mathrm{C}$ in $60 \mathrm{ml}$ phosphate saline buffer containing $600 \mu \mathrm{l}$ of anti- $\alpha_{\mathrm{s} 1}$-casein antiserum and then washed 3-4 times for $1 / 2 \mathrm{~h}$ at room temperature. Subsequently the membrane was incubated at $37^{\circ} \mathrm{C}$ for $2-3 \mathrm{~h}$ in a solution of $100 \mu \mathrm{l}$ peroxidase labelled goat antirabbit $\operatorname{IgG}(\mathrm{H}=\mathrm{L})$ antibodies (Institut Pasteur) in $50 \mathrm{ml}$ phosphate buffer, washed 2-3 times for $1 / 2$ to $1 \mathrm{~h}$ at room temperature and the peroxidase activity revealed with a solution of diaminobenzidine.

\section{E. Rocket Immunoelectrophoresis}

Rocket immunoelectrophoresis (LAURELL, 1966) was performed on pretreated LKB plates in a gel $(8.5 \times 9 \mathrm{~cm}$; volume : $12 \mathrm{ml})$ containing $1 \mathrm{p} .100(\mathrm{w} / \mathrm{v})$ agarose (LKB) and $0.025 \mathrm{M}$ veronal buffer $\mathrm{pH} 8.6$ with $600 \mu \mathrm{l}$ antiserum being added per gel. Casein samples were diluted in the veronal buffer : $1 / 100 \mathrm{w} / \mathrm{v}$ for $\alpha_{\mathrm{s} 2}$-casein and $\kappa$-casein ; $1 / 300$ for $\beta$-casein and $1 / 20,1 / 50$ or $1 / 100$ for $\alpha_{\text {s1 }}$-casein depending on the genotype ; 3 or $4 \mu \mathrm{l}$ of casein solution were applied in $1.5 \mathrm{~mm}$ diameter wells under a $30 \mathrm{~V}$ and $8 \mathrm{~mA}$ current. The electrode vessel contained veronal buffer $0.05 \mathrm{M} \mathrm{pH}$ 8.6. A $150 \mathrm{~V}$ current was applied overnight at $15^{\circ} \mathrm{C}$. Washing, drying, staining and destaining of the gels were carried out according to WEEKE (1976). Quantification of proteins was made by measurement of the peak heights with reference to standards of known concentrations.

\section{F. Preparation and amino-acid composition of $\alpha_{\mathrm{sl}}$-casein of type $F$}

Aliquots of $2 \mathrm{ml}$ of a $5 \mathrm{p} .100$ solution of whole casein of type $\mathrm{F}$, reduced according to WoxchIK (1964) were chromatographed on a cation exchanger Mono S HR 10/10 column $(1 \times 10 \mathrm{~cm}$; Pharmacia) using the FPLC system of Pharmacia. Elution was carried out at room temperature in a $75 \mathrm{mM}$ formate-7.5 M urea, pH 4.0, buffer with a $\mathrm{NaCl}$ linear gradient $(0.1$ to $0.26 \mathrm{M} ; 1.5 \mathrm{ml} / \mathrm{min})$ for $60 \mathrm{~min}$. A 
repetition of 15 successive chromatographies was necessary to obtain $13 \mathrm{mg}$ of fraction $\alpha_{s 1}-C n F$ (yield : 0.9 p. 100 of the whole casein).

The amino-acid composition of this fraction was established using a Biotronik LC 5000 analyzer.

\section{G. Quantification of milk proteins}

Individual lactosera were prepared immediately after milking by rennet coagulation followed by paper filtration. Total rennet-casein content (TC) was determined with a Milko-Scan 104 equipment and was obtained as the difference between the nitrogen content of milk and that of lactoserum with a specific calibration of the apparatus for the 2 measures. The reference method used for calibration was the Kjeldahl method (FIL-IDF-E-Doc 214-1985).

\section{Results}

\section{A. Identification of allele $\alpha_{\mathrm{s} 1}-C n^{F}$}

With only a few exceptions, all samples which were collected for genetic investigations were tested in both acid SGE and SDS-PAGE. Patterns obtained by SDS-PAGE could therefore be interpreted with reference to the nomenclature proposed by Boulanger et al. (1984) using SGE. In SDS-PAGE, the 2 known variants of $\alpha_{\mathrm{s} 2}$-casein, $\alpha_{\mathrm{s} 2}-\mathrm{Cn} A$ and $B$, were separated and all samples showed the same faster migrating minor band (m) of $\alpha_{\mathrm{s} 2}$-casein (fig. 1). The $\alpha_{\mathrm{s} 1}-\mathrm{Cn} \mathrm{C}$ and $\alpha_{\mathrm{s} 1}-\mathrm{Cn} \mathrm{B}$ variants were not separable in SDS-PAGE [their common band will hereafter be designated by (B)] while $\alpha_{\mathrm{s1}}-\mathrm{Cn}$ A migrated faster and was well resolved (fig. 1). Milks classified according to Boulanger et al. (1984) as null types had no $\alpha_{\mathrm{s1}}$-casein fraction in this region. However, all these samples but one (designated later as $\alpha_{\mathrm{sl}}-\mathrm{Cn}^{\circ} / \alpha_{\mathrm{s} 1}-\mathrm{Cn}^{\circ}$ ) showed a faint double band, designated $F$, in front of $\beta$-casein, which was also present in some of milks possessing either the $\alpha_{\mathrm{s1}}-\mathrm{Cn} \mathrm{A}$ or the $\alpha_{\mathrm{s} 1} \mathrm{Cn}$ (B) band.

Fraction F, which was purified by FPLC, had the following amino-acid composition which is comparable to that given by Boulanger et al. (1984) for goat $\alpha_{\mathrm{s} 1}$-casein B : Asx : 19.0 (19) ; Thr : (7) ; Ser : (12) ; Glx : 35.3 (35) ; Pro : 21.7 (22) ; Gly : 9.7 (10) ; Ala : 11.0 (11) ; Val : 9.4 (9) ; Met : 4.4 (4) ; Ile : 8.6 (9) ; Leu : 17.2 (19) ; Tyr: 9.2 (9) ; Phe : 8.7 (9) ; His : 6.1 (6) ; Lys : 12.8 (13) ; Arg : 6.3 (6). On immunoblotting, the double band $F$ reacted with anti- $\alpha_{\mathrm{sl}}$-casein antibodies (fig. 2 ).

These results suggested that the double band $F$ was under control of an allele of locus $\alpha_{\mathrm{s} 1}-\mathrm{Cn}$, called $\alpha_{\mathrm{s} 1}-\mathrm{Cn}^{\mathrm{F}}$, a hypothesis supported by the following. Firstly, the double band $F$ has not been observed in milks from animals of genotype $\alpha_{s 1}-\mathrm{Cn}^{\mathrm{A}} / \alpha_{\mathrm{s1}}-\mathrm{Cn}^{(B)}$. Secondly, segregation data in families with heterozygous dams, shown in table 1 , fit with the expected Mendelian ratios (the other dam's genotypes may include the $\alpha_{\mathrm{s} 1}-\mathrm{Cn}^{\circ}$ allele described hereafter). Thirdly, in the progeny of sires transmitting band (B) or bands $F$ to their daughters, thus supposed to be of genotype $\alpha_{s 1}-\mathrm{Cn}^{(\mathrm{B})} / \alpha_{\mathrm{sl}}-\mathrm{Cn}^{\mathrm{F}}$, band (B) was transmitted 66 times, bands F, 72 times, which is not different from the expected $1: 1$ ratio. The occurrence of milks with a low amount of $\alpha_{\mathrm{s1}}$-casein, improperly called 


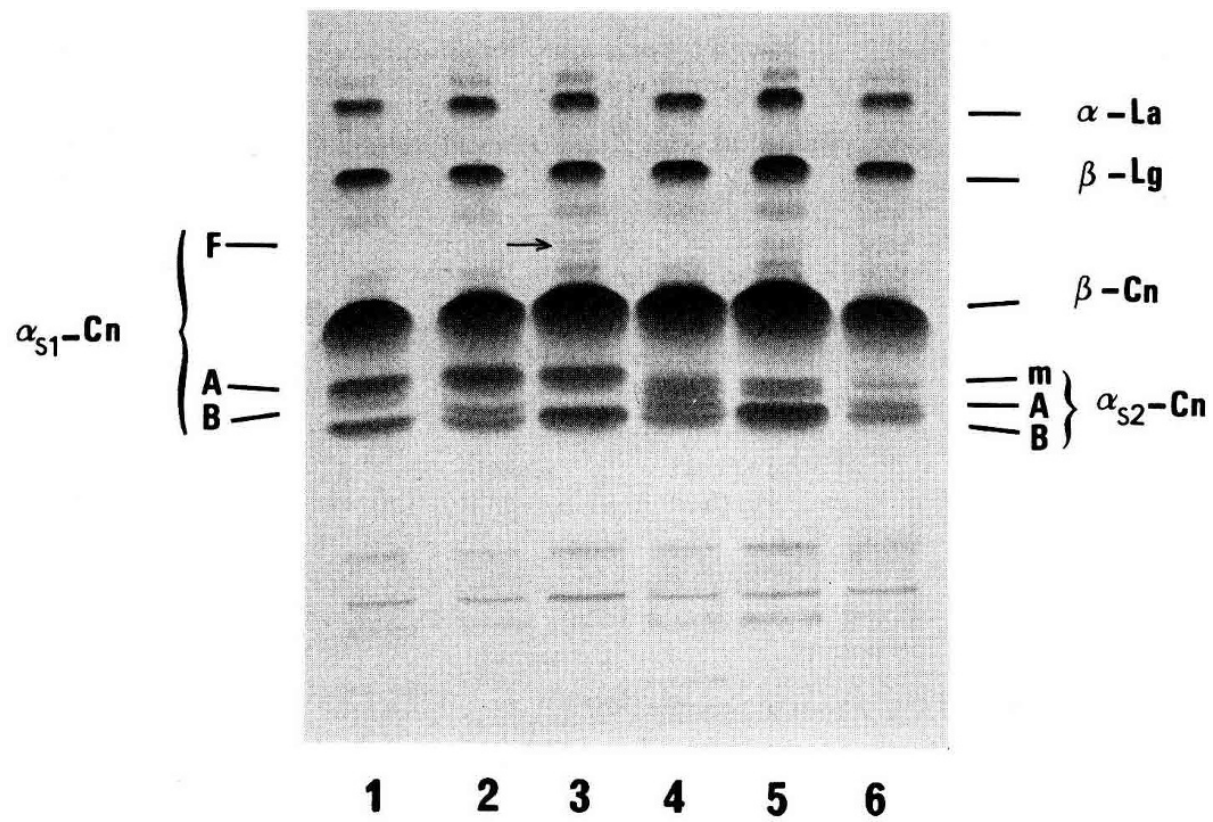

FIG. 1

SDS-polyacrylamide gel electrophoresis of 6 individual goat milks. Samples 2, 4 and 6 are heterozygous at locus $\alpha_{s 2^{-}} C n\left(\alpha_{s 2}{ }^{-C} n^{A} / \alpha_{s 2^{-}}-C n^{B}\right) ; m=$ minor $\alpha_{s 2}$-casein fraction. The $\alpha_{s t}$ casein phenotypes are as follows: $1=A B^{-} ; 2=A ; 3=A F ; 4=B^{-} ; 5=B^{-} F ; 6=F$.

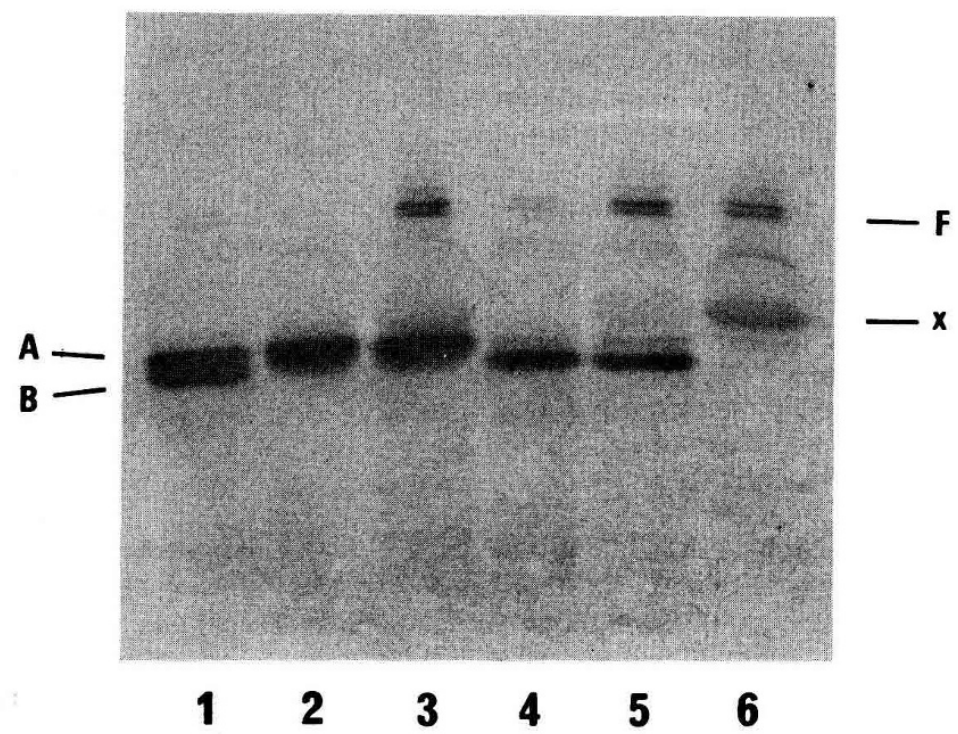

FIG. 2

Immunoblotting of $\alpha_{\mathrm{s} 1}$ casein for the same milk samples as in fig. $1 ; x=$ fraction only present in some of $\alpha_{s 1}{ }^{-} C n F$ phenotypes (see text). 
TABLE 1

Segregation of $\alpha_{S /}$-casein polymorphism in sire-dam-daughter families.

\begin{tabular}{|c|c|c|c|c|c|c|}
\hline \multirow{2}{*}{ Phenotype of dams } & \multicolumn{6}{|c|}{ Phenotype of daughters } \\
\hline & A & $A(B)$ & $\mathbf{A F}$ & (B) & (B)F & $\mathrm{F}$ \\
\hline$A \ldots \ldots \ldots \ldots \ldots$ & 4 & & & & & \\
\hline $\mathrm{A}(\mathrm{B}) \ldots \ldots \ldots \ldots \ldots$ & 2 & 2 & & & & \\
\hline$\ldots \ldots \ldots \ldots$ & $4^{*}$ & 8 & & & & \\
\hline$(B) F \ldots \ldots \ldots \ldots \ldots$ & & 11 & 10 & & & \\
\hline (F) $\ldots \ldots \ldots \ldots \ldots \ldots \ldots$ & $3 *$ & & 11 & & & \\
\hline
\end{tabular}

b

\begin{tabular}{|c|c|c|c|c|c|c|}
\hline \multirow{2}{*}{ Phenotype of dams } & \multicolumn{6}{|c|}{ Phenotype of daughters } \\
\hline & A & $\mathbf{A}(\mathbf{B})$ & AF & (B) & (B)F & $\mathbf{F}$ \\
\hline $\mathbf{A} \ldots \ldots \ldots \ldots \ldots \ldots$ & & 3 & 2 & & 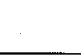 & $2^{*}$ \\
\hline $\mathrm{A}(\mathrm{B}) \ldots \ldots \ldots \ldots \ldots$ & & 2 & 7 & 5 & 4 & \\
\hline AF $\ldots \ldots \ldots \ldots \ldots$ & & 5 & 2 & & 4 & 9 \\
\hline (B) $\ldots \ldots \ldots \ldots \ldots \ldots$ & & & & 16 & 8 & $1^{*}$ \\
\hline$(\mathrm{B}) \mathbf{F} \ldots \ldots \ldots \ldots \ldots \ldots$ & & & & 15 & 41 & 15 \\
\hline $\mathbf{F} \ldots \ldots \ldots \ldots \ldots \ldots$ & & & & $1^{*}$ & 15 & 22 \\
\hline
\end{tabular}

c

\begin{tabular}{|c|c|c|c|c|c|c|}
\hline \multirow{2}{*}{ Phenotype of dams } & \multicolumn{6}{|c|}{ Phenotype of daughters } \\
\hline & A & $\mathbf{A}(\mathbf{B})$ & AF & (B) & (B)F & $\mathbf{F}$ \\
\hline A $\ldots \ldots \ldots \ldots \ldots$ & & 2 & & $1^{*}$ & & \\
\hline $\mathrm{A}(\mathrm{B}) \ldots \ldots \ldots \ldots \ldots \ldots$ & & 1 & & & & \\
\hline AF $\ldots \ldots \ldots \ldots \ldots \ldots$ & & 3 & & & 5 & \\
\hline (B) $\ldots \ldots \ldots \ldots \ldots \ldots \ldots$ & & & & 25 & & \\
\hline$(\mathbf{B}) \mathrm{F} \ldots \ldots \ldots \ldots \ldots \ldots$ & & & & 17 & 26 & $1 * *$ \\
\hline $\mathbf{F} \ldots \ldots \ldots \ldots \ldots \ldots$ & & & & $2 *$ & 13 & \\
\hline
\end{tabular}

In this table $(B)=B$ or $C$.

a : one sire, of genotype $\alpha_{s 1}-\mathrm{Cn}^{\mathrm{A}} / \alpha_{s 1}-\mathrm{Cn}^{\mathrm{A}}$.

b : 9 sires, all of genotype $\alpha_{s 1}-\mathrm{Cn}^{\mathrm{B}} / \alpha_{\mathrm{s1}}-\mathrm{Cn}^{\mathrm{F}}$.

c : 4 sires, all of genotype $\alpha_{s 1}-\mathrm{Cn}^{\mathrm{B}} / \alpha_{\mathrm{s1}}-\mathrm{Cn}^{\mathrm{B}}$.

* Data explained by the existence of allele $\alpha_{\mathrm{s1}}-\mathrm{Cn}^{\circ}$.

The proportions in lines $\mathrm{a}-\mathrm{AB}, \mathrm{a}-(\mathrm{B}) \mathrm{F}, \mathrm{c}-\mathrm{AF}$ and $\mathrm{c}-(\mathrm{B}) \mathrm{F}\left(\chi^{2}=1.88\right.$ with $\left.1 \mathrm{df}\right)$ are not significantly different from $1: 1$ ratio (in line $c-(B) F:{ }^{* *}$ is interpreted as an error of parentage); the proportions in lines $b-A(B)$ and $b-A F$ are not significantly different from 1:1:1:1: ratio, in line $b-(B) F$, from $1: 2: 1\left(x^{2}=1.7\right.$ with 2 df $)$. 
" null types " by Boulanger et al. (1984) was thus accounted for by the existence of allele $\alpha_{s 1}-\mathrm{Cn}^{\mathrm{F}}$. Some of the milks showed an additional band $(\mathrm{x})$ which migrated slightly slower than $\beta$-casein and reacted with anti- $\alpha_{\mathrm{sl}}$-casein antibodies (fig. 2). The nature of this fraction which curiously was present only in the milk of certain dams, and was not transmitted to their daughters, remains to be established. The immunoblotting results demonstrated the apparent presence of the double band of type $F$ in all milks, but it was much weaker in those milks without a visible protein band in this region of the SDS-PAGE pattern.

\section{B. Identification of allele $\alpha_{\mathrm{s} 1}-\mathrm{Cn}^{o}$}

Segregation data in 14 families of table 1 (4.5 p. 100 of all families, marked with an asterisk) could not be explained under the 3 allele hypothesis $\left(\alpha_{s 1}-\mathrm{Cn}^{\mathrm{A}}, \alpha_{\mathrm{s1}}-\mathrm{Cn}^{(\mathrm{B})}, \alpha_{\mathrm{s1}}-\right.$ $\mathrm{Cn}^{\mathrm{F}}$ ). Although errors in registration of parentages do occur, it is unlikely that they would account for the 4.5 p. 100 exceptions. In 11 of the 14 cases, the daughter had inherited allele $\alpha_{\mathrm{s} 2}-\mathrm{Cn}^{\mathrm{B}}$ from the dam, a proportion not due to chance since the frequency of $\alpha_{\mathrm{s} 2}-\mathrm{Cn}^{\mathrm{B}}$ in the sample was only 0.08. Because loci $\alpha_{\mathrm{s} 1}-\mathrm{Cn}$ and $\alpha_{\mathrm{s2}}-\mathrm{Cn}$ are closely linked, as suggested by Boulanger et al. (1984) and confirmed in this paper, these observations led one to suspect the existence of a true null allele, $\alpha_{s 1}-\mathrm{Cn}^{\circ}$, associated in a haplotype with $\alpha_{\mathrm{s} 2}-\mathrm{Cn}^{\mathrm{B}}$. In fact, the only dam homozygous for $\alpha_{\mathrm{s} 2}-\mathrm{Cn}^{\mathrm{B}}$ and therefore also possibly homozygous for $\alpha_{s 1}-\mathrm{Cn}^{\circ}$, had no double band of type $\mathrm{F}$ or any other $\alpha_{s 1}$-casein (fig. 3). In addition, one sire (Saxon 7903981036 ; family not

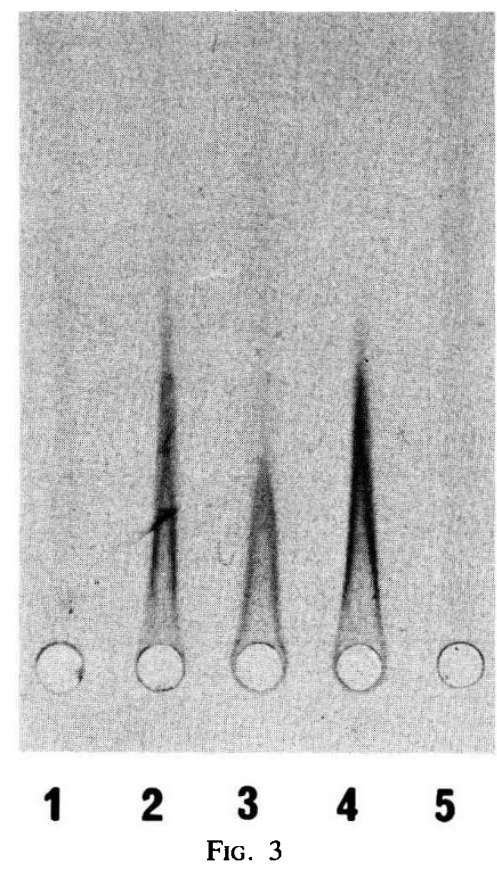

Rocket immunoelectrophoresis of milk from the individual of genotype $\alpha_{\mathrm{s1}}-\mathrm{Cn} / \mathrm{\alpha}_{\mathrm{s1}}-\mathrm{Cn} \mathrm{n}^{o}(\mathrm{l}=$ dilution $1 / 20 ; 5=1 / 30)$ compared to milk from individuals of phenotypes $A(2=1 / 100), F(3=1 /$ 20) and $B^{-}(4=1 / 50)$ using anti- $\alpha_{\mathrm{s} 1}$-casein antibodies. 
included in table 1) of genotype $\alpha_{\mathrm{s} 2}-\mathrm{Cn}^{\mathrm{A}} / \alpha_{\mathrm{s} 2}-\mathrm{Cn}^{\mathrm{B}}$, obviously possessed haplotype $\alpha_{\mathrm{s} 1}-\mathrm{Cn}^{\mathrm{O}}$ $\alpha_{\mathrm{s} 2}-\mathrm{Cn}^{\mathrm{B}}$, because he transmitted $\alpha_{\mathrm{s} 2}-\mathrm{Cn}^{\mathrm{B}}$ to 7 of his 13 daughters, with no detectable $\alpha_{\mathrm{s} 1}{ }^{-}$ casein fraction. The existence of a true null and formally recessive allele was thus - established.

\section{Identification of allele $\alpha_{\mathrm{s} 1}{ }^{-} \mathrm{Cn}^{B^{-}}$}

Boulanger et al. (1984) concluded that $\alpha_{\mathrm{s} 1}$-Cn B existed in at least 2 variant forms differing in their synthesis rates and with one of the forms being present in the so called "null types". The results of the present paper do not support the latter conclusion in that $\alpha_{\mathrm{s} 1}-\mathrm{Cn} F$ does not have the electrophoretic properties of $\alpha_{\mathrm{s} 1}-\mathrm{Cn} \mathrm{B}$. Nevertheless, the SDS-PAGE patterns still reveals 2 quantitative levels of $\alpha_{\mathrm{s} 1}-\mathrm{Cn} B$, called $\alpha_{\mathrm{s} 1}-\mathrm{Cn} \mathrm{B}$ and $\alpha_{\mathrm{s1}}-\mathrm{Cn} \mathrm{B} \mathrm{B}^{-}$. The concentration of $\alpha_{\mathrm{s1}}-\mathrm{Cn} \mathrm{B}$ is comparable to that of $\alpha_{s 1}-\mathrm{Cn} \mathrm{A}$ and $\alpha_{\mathrm{s1}}-\mathrm{Cn} \mathrm{C}$, while that of $\alpha_{\mathrm{s1}}-\mathrm{Cn} \mathrm{B}^{-}$is much lower. Although the discrimination between the 2 levels was not easy in a few milks, the $\mathrm{B}$ and $\mathrm{B}^{-}$patterns were repeatable within and between lactations and transmitted in a Mendelian fashion.

In conclusion, the polymorphism of goat $\alpha_{\mathrm{s} 1}$-casein is under control of a minimum of 6 alleles, $\alpha_{s 1}-\mathrm{Cn}^{\mathrm{A}}, \alpha_{\mathrm{s} 1}-\mathrm{Cn}^{\mathrm{B}}, \alpha_{\mathrm{s1}}-\mathrm{Cn}^{\mathrm{C}}, \alpha_{\mathrm{s1}}-\mathrm{Cn}^{\mathrm{B}^{-}}, \alpha_{\mathrm{s} 1}-\mathrm{Cn}^{\mathrm{F}}$ and $\alpha_{\mathrm{s1}}-\mathrm{Cn}^{\mathrm{O}}$.

\section{Allelic frequencies}

The frequencies of $\alpha_{s 1}-\mathrm{Cn}^{\mathrm{A}}, \alpha_{\mathrm{s1}}-\mathrm{Cn}^{\mathrm{B}+\mathrm{C}}, \alpha_{\mathrm{s1}}-\mathrm{Cn}^{\mathrm{B}^{-}}, \alpha_{\mathrm{s1}}-\mathrm{Cn}^{\mathrm{F}}$ and $\alpha_{\mathrm{s1}}-\mathrm{Cn}^{\circ}$ were estimated from SDS-PAGE data by the iterative method of CEPPELLINI et al. (1956) and the frequency of $\alpha_{\mathrm{s1}}-\mathrm{Cn}^{\mathrm{c}}$ by gene counting from acid SGE data. In the group of 213 Alpine dams from 49 flocks of West Central France, the frequencies were : $\alpha_{\mathrm{s1}}-\mathrm{Cn}^{\mathrm{A}}=0.14$; $\alpha_{s 1}-\mathrm{Cn}^{\mathrm{B}}=0.05 ; \alpha_{\mathrm{s1}}-\mathrm{Cn}^{\mathrm{C}}=0.01 ; \alpha_{\mathrm{s1}}-\mathrm{Cn}^{\mathrm{B}^{-}}=0.34 ; \alpha_{\mathrm{s1}}-\mathrm{Cn}^{\mathrm{F}}=0.41 ; \alpha_{\mathrm{s1}}-\mathrm{Cn}^{\mathrm{O}}=0.05$. In the group of 159 Saanen dams from 52 flocks from the same area, the frequencies were : $\alpha_{s 1}-\mathrm{Cn}^{\mathrm{A}}=0.07 ; \alpha_{\mathrm{s} 1}-\mathrm{Cn}^{\mathrm{B}}=0.06 ; \alpha_{\mathrm{s} 1}-\mathrm{Cn}^{\mathrm{C}}=0 ; \alpha_{\mathrm{s} 1}-\mathrm{Cn}^{\mathrm{B}^{-}}=0.41 ; \alpha_{\mathrm{s} 1}-\mathrm{Cn}^{\mathrm{F}}=0.43 ;$ $\alpha_{\mathrm{s} 1}-\mathrm{Cn}^{\mathrm{O}}=0.03$.

\section{E. Linkage of $\alpha_{\mathrm{s} 1}-C n$ and $\alpha_{\mathrm{s} 2}-C n$}

Boulanger et al. (1984) suggested linkage between loci $\alpha_{\mathrm{s} 1}-\mathrm{Cn}$ and $\alpha_{\mathrm{s} 2}-\mathrm{Cn}$ because, in 12 informative sire-dam-daughter families, the sires transmitted only 2 haplotypes $\left(\alpha_{\mathrm{s} 1}-\mathrm{Cn}^{\mathrm{A}}-\alpha_{\mathrm{s} 2}-\mathrm{Cn}^{\mathrm{B}}\right.$ and $\left.\alpha_{\mathrm{s} 1}-\mathrm{Cn}^{(\mathrm{B})}-\alpha_{\mathrm{s} 2}-\mathrm{Cn}^{\mathrm{A}}\right)$. In the present study, 10 additional informative cases were observed in the family of one sire which transmitted only 2 haplotypes : $\alpha_{\mathrm{s} 1^{-}}$ $\mathrm{Cn}^{\mathrm{B}^{-}}-\alpha_{\mathrm{s} 2}-\mathrm{Cn}^{\mathrm{B}}$ (6 times) and $\alpha_{\mathrm{s} 1}-\mathrm{Cn}^{\mathrm{F}}-\alpha_{\mathrm{s} 2}-\mathrm{Cn}^{\mathrm{A}}$ (4 times). This brings to 22 the number of informative families without recombinants, a result confirming that loci $\alpha_{\mathrm{s} 1}-\mathrm{Cn}$ and $\alpha_{\mathrm{s} 2}-$ $\mathrm{Cn}$ are closely linked in the goat as in the cow (Grosclaude et al., 1978).

\section{F. Preliminary results on quantitative aspects}

Figure 4 represents the distribution of the $\alpha_{\mathrm{s} 1}$-casein contents of 251 individual milks collected in April 1986 at the «Station de Testage caprin » near Moissac. The 1st mode corresponds essentially to phenotypes $F$, the 2 nd one to phenotypes $B^{-}$and $B^{-} F$, 


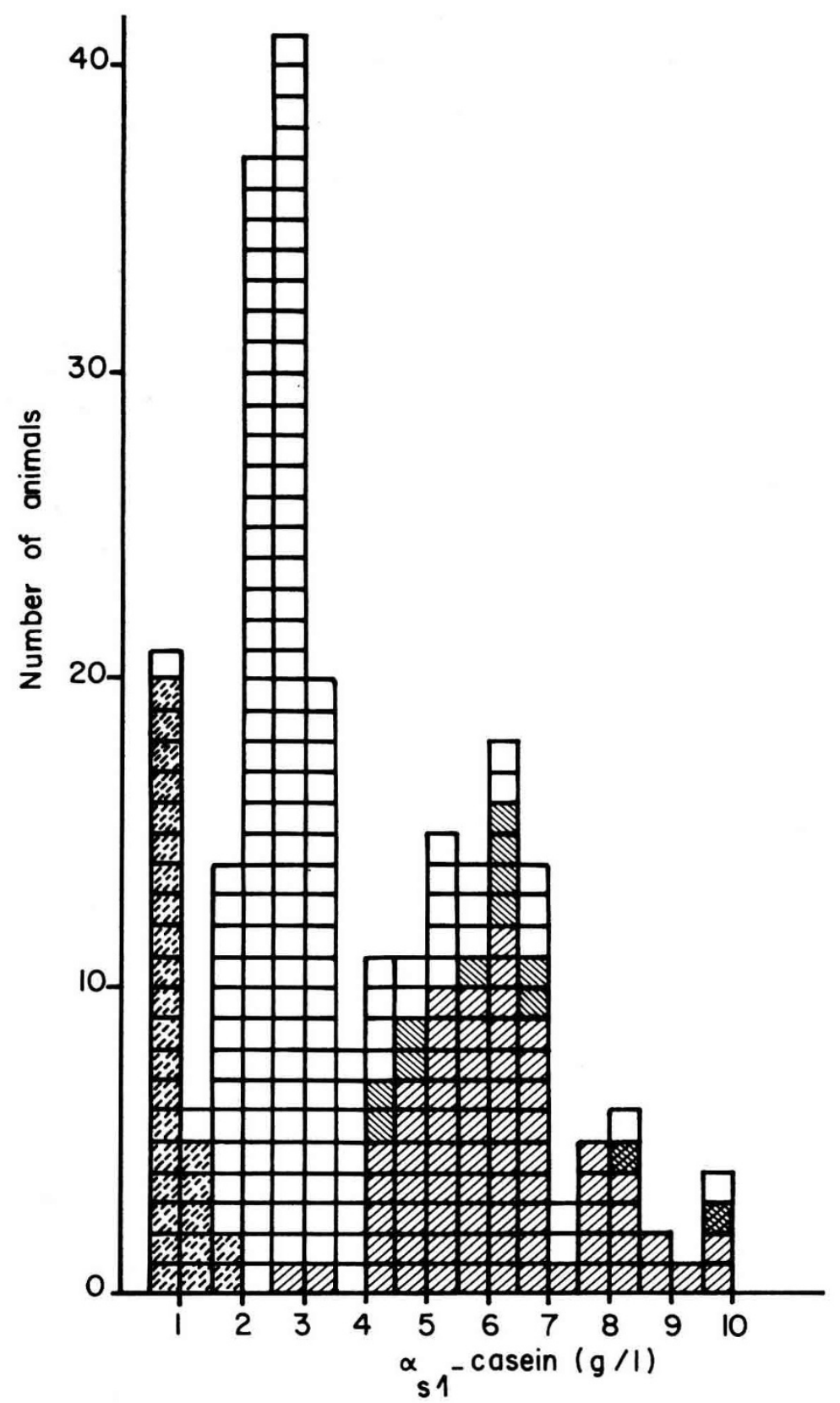

FIG. 4

Distribution of the $\alpha_{\mathrm{s} 1}$ casein contents of individual milks in a large flock.

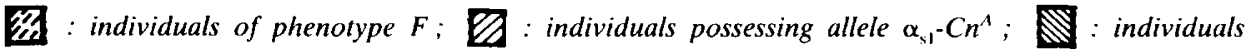
possessing allele $\alpha_{\mathrm{s} 1}{ }^{-} \mathrm{Cn}^{\prime} ; \square$ Ist and 2nd modes : individuals of phenotype $B F$ or $B^{-}$; other modes : individuals of phenotype $B F$ or $B$. There is no individual homozygous for allele $\alpha_{\mathrm{s} 1}-C^{\prime \prime}$. 
the 3rd to genotypes including alleles $\alpha_{\mathrm{st}}-\mathrm{Cn}^{\mathrm{A}}, \alpha_{\mathrm{st}}-\mathrm{Cn}^{\mathrm{B}}$ or $\alpha_{\mathrm{st}}-\mathrm{Cn}^{\mathrm{C}}$ and the genotypes with 2 doses of the latter alleles being found at the extreme right of the distribution. The rather clear cut distinction between different phenotypes, illustrated by the plurimodality of the histogram, is a straightforward confirmation of the visual interpretation of electrophoregrams. This holds true in particular for the discrimination between phenotypes $\mathrm{B}$ and $\mathrm{B}^{-}$, but also for the fact that a few $\mathrm{B}$ type phenotypes are difficult to classify. Note also that individuals with one $\alpha_{\mathrm{s} 1}-\mathrm{Cn}^{\mathrm{A}}$ or one $\alpha_{\mathrm{s} 1}-\mathrm{Cn}^{\mathrm{C}}$ allele are found in the very same zone.

With the same milk samples, a correlation of 0.68 was found between the $\alpha_{\text {s1 }}$ and the rennet-casein contents (for $\mathrm{Ho}=0, \mathrm{P}<10^{-4}$ ). The increase of rennet-casein content as a function of $\alpha_{\mathrm{s} 1}$-casein content is given by $\mathrm{TC}=19.59+0.64 \alpha_{\mathrm{s} 1}$ (in $\mathrm{g} / \mathrm{kg}$; standard error of $b=0.04$ ).

The contents of the individual caseins in milks from animals of different genotypes were estimated by rocket immunoelectrophoresis. Table 2 gives the results obtained for 4 genotypes $\left(\alpha_{\mathrm{sl}}-\mathrm{Cn}^{\mathrm{F}} / \alpha_{\mathrm{s} 1}-\mathrm{Cn}^{\mathrm{F}}=25\right.$ individuals from 14 different farms; $\alpha_{\mathrm{st}}-\mathrm{Cn}^{\mathrm{B}^{-}} / \alpha_{\mathrm{s} 1^{-}}$ $\left.\mathrm{Cn}^{\mathrm{F}}=18,14 ; \alpha_{\mathrm{s1}}-\mathrm{Cn}^{\mathrm{A}} / \alpha_{\mathrm{s} 1}-\mathrm{Cn}^{\mathrm{F}}=20,11 ; \alpha_{\mathrm{s1}}-\mathrm{Cn}^{\mathrm{A}} / \alpha_{\mathrm{s} 1}-\mathrm{Cn}^{\mathrm{B}^{-}}=24,11\right)$. The numbers of individuals with other genotypes were too low for statistical analyses. The $F$ test for heterogeneity of means was highly significant for $\alpha_{\mathrm{s} 1}$-casein $\left(\mathrm{F}: 74.26 ; \mathrm{P}<10^{-4}\right), \alpha_{\mathrm{s} 2}$ casein $\left(\mathrm{F}: 13.79 ; \mathrm{P}<10^{-4}\right)$ and total casein $\left(\mathrm{F}: 7.51 ; \mathrm{P}<2.10^{-4}\right)$ but non significant for $\beta$-and $\kappa$-caseins. The Student-Newman-Keuls test confirms the significant superiority in milk $\alpha_{\mathrm{s} 1}$-casein content of genotype $\alpha_{\mathrm{s} 1}-\mathrm{Cn}^{\mathrm{B}^{-}} / \alpha_{\mathrm{s} 1}-\mathrm{Cn}^{\mathrm{F}}$ as compared to genotype $\alpha_{\mathrm{s} 1}{ }^{-}$ $\mathrm{Cn}^{\mathrm{F}} / \alpha_{\mathrm{s} 1^{-}}-\mathrm{Cn}^{\mathrm{F}}$, as well as the significant superiority in milk $\alpha_{\mathrm{s} 1^{-}}, \alpha_{\mathrm{s} 2^{-}}$and total casein content of the 2 genotypes possessing allele $\alpha_{\mathrm{s} 1}-\mathrm{Cn}^{\mathrm{A}}$ as compared to the 2 genotypes without this allele. Assuming an additive contribution of each allele, and based on values obtained for the first 3 genotypes of table 2 , the contribution of the alleles considered to the milk $\alpha_{\mathrm{s1}}$-casein content is as follows : $\alpha_{\mathrm{s1}}-\mathrm{Cn}^{\mathrm{F}}=0.6 \mathrm{~g} / 1 ; \alpha_{\mathrm{s1}}{ }^{-}$ $\mathrm{Cn}^{\mathrm{B}^{-}}=1.6 \mathrm{~g} / 1 ; \alpha_{\mathrm{s} 1}-\mathrm{Cn}^{\mathrm{A}}=3.6 \mathrm{~g} / \mathrm{l}$. Because of the relatively small sample size these values should only be considered as approximative. Note that the $\alpha_{\mathrm{s1}}$-casein contents of milks from genotypes $\alpha_{\mathrm{s} 1}-\mathrm{Cn}^{\mathrm{A}} / \alpha_{\mathrm{s} 1}-\mathrm{Cn}^{\mathrm{B}^{\mathrm{B}}}$ and $\alpha_{\mathrm{s} 1}-\mathrm{Cn}^{\mathrm{A}} / \alpha_{\mathrm{s} 1}-\mathrm{Cn}^{\mathrm{F}}$ are not significantly different, a result which needs further confirmation.

TABlE 2

Content $(\mathrm{g} / \mathrm{l})$ in $\alpha_{s l^{-}}, \alpha_{s 2^{-}}, \beta-, \kappa-$ and total casein of milks from goats of 4 different genotypes at locus $\alpha_{s I}-C n$ (means and standard deviations).

\begin{tabular}{|c|c|c|c|c|}
\hline \multirow[b]{2}{*}{ Caseins } & \multicolumn{4}{|c|}{ Genotype at locus $\alpha_{\mathrm{s1}}-\mathrm{Cn}$ and number of individuals $(\mathrm{N})$} \\
\hline & $\begin{array}{c}\mathbf{F} / \mathbf{F} \\
\mathbf{N}=25\end{array}$ & $\begin{array}{c}\mathbf{B}^{-} / \mathbf{F} \\
\mathbf{N}=18\end{array}$ & $\begin{array}{c}A / F \\
N=20\end{array}$ & $\begin{array}{c}\mathrm{A} / \mathrm{B}^{-} \\
\mathrm{N}=24\end{array}$ \\
\hline$\alpha_{\mathrm{s} 1}$ & $1.21 \pm 0.70 \mathrm{a}$ & $2.24 \pm 0.37 \mathrm{~b}$ & $4.26 \pm 0.95 \mathrm{c}$ & $4.03 \pm 1.01 \mathrm{c}$ \\
\hline$\alpha_{\mathrm{s} 2}$ & $3.94 \pm 1.43 \mathrm{a}$ & $4.12 \pm 1.52 \mathrm{a}$ & $5.76 \pm 1.47 \mathrm{~b}$ & $6.11 \pm 1.29 b$ \\
\hline$\beta$ & $10.29 \pm 3.50 \mathrm{a}$ & $9.56 \pm 2.26 \mathrm{a}$ & $11.22 \pm 2.12 \mathrm{a}$ & $10.96 \pm 2.62 \mathrm{a}$ \\
\hline$\kappa$ & $7.30 \pm 2.80 \mathrm{a}$ & $6.51 \pm 1.97 \mathrm{a}$ & $7.72 \pm 1.74 \mathrm{a}$ & $7.66 \pm 1.77 \mathrm{a}$ \\
\hline Total & $22.74 \pm 7.54 \mathrm{a}$ & $22.43 \pm 5.22 \mathrm{a}$ & $28.96 \pm 5.28 b$ & $28.76 \pm 5.77 b$ \\
\hline
\end{tabular}

For $F / F$, read : $\alpha_{s 1}-\mathrm{Cn}^{F} / \alpha_{s 1}-\mathrm{Cn}^{F}$, etc. ; a, b, c = comparison of means by the Student-Newman-Keuls test : 2 identical letters in the same line correspond to non significantly different means, 2 different letters to significantly different means. 
Along the same line, the higher $\alpha_{s 1}$-casein content of milk from genotype $\alpha_{\mathrm{s1}}-\mathrm{Cn}^{\mathrm{B}}{ }^{-}$/ $\alpha_{s 1}-\mathrm{Cn}^{\mathrm{F}}$ as compared to that from genotype $\alpha_{\mathrm{s} 1}-\mathrm{Cn}^{\mathrm{F}} / \alpha_{\mathrm{s1}}-\mathrm{Cn}^{\mathrm{F}}$, which illustrates the superiority of allele $\alpha_{s 1}-\mathrm{Cn}^{\mathrm{B}^{-}}$upon allele $\alpha_{\mathrm{s1}}-\mathrm{Cn}^{\mathrm{F}}$, appears to be balanced by a decrease (although not statistically significant) in $\beta$ - and $\kappa$-casein contents. However the full significance of this result is questionable, knowing that withdrawing individuals possessing allele $\alpha_{\mathrm{s} 1}-\mathrm{Cn}^{\mathrm{A}}$ from the group of Moissac animals, which increases the stastistical weight of allele $\alpha_{\mathrm{s} 1} \mathrm{CC}^{\mathrm{B}^{-}}$, doesn't affect the regression coefficient of TC on $\alpha_{\mathrm{s} 1}$ $\left(\mathrm{TC}=19.53+0.66 \alpha_{\mathrm{sl}}\right.$, with standard error of $\left.\mathrm{b}=0.06\right)$.

\section{Discussion}

The occurrence at the caprine $\alpha_{\mathrm{s} 1}$-casein locus of alleles associated with a high $\left(\alpha_{\mathrm{s} 1}\right.$ $\left.\mathrm{Cn}^{\mathrm{A}}, \alpha_{\mathrm{s} 1}-\mathrm{Cn}^{\mathrm{B}}, \alpha_{\mathrm{s} 1}-\mathrm{Cn}^{\mathrm{C}}\right)$, an intermediate $\left(\alpha_{\mathrm{s} 1}-\mathrm{Cn}^{\mathrm{B}}\right)$, a weak $\left(\alpha_{\mathrm{s} 1}-\mathrm{Cn}^{\mathrm{F}}\right)$ and a null $\left(\alpha_{\mathrm{s} 1}-\mathrm{Cn}^{\mathrm{O}}\right)$ synthesis rate, which has no counterpart in the cow, is of special interest. The existence, in or near the caprine $\alpha_{\mathrm{s1}}$-Cn locus, of a structural feature responsible for the generation of abnormal allelic forms can be suspected. In this respect, an analysis of the goat casein cluster of genes at the DNA level should be all the more informative as the alterations specific to alleles $\alpha_{\mathrm{s} 1}-\mathrm{Cn}^{\mathrm{B}^{-}}, \alpha_{\mathrm{s} 1}-\mathrm{Cn}^{\mathrm{F}}$ and $\alpha_{\mathrm{s} 1}-\mathrm{Cn}^{\mathrm{O}}$ have dramatically different effects and thus possibly affect distinct DNA regulatory sites. Among the variants, $\alpha_{\mathrm{s} 1}-\mathrm{Cn} \mathrm{F}$ shows atypical electrophoretic properties. A biochemical analysis of this casein fraction could contribute to the identification of the nature of the underlying mutation.

It is interesting to note that a mutation affecting the activity of the $\alpha_{\mathrm{s1}}-\mathrm{Cn}$ locus may also influence that of the closely linked $\alpha_{s 2}-\mathrm{Cn}$ locus. More research is needed to measure accurately the rates of synthesis of the 4 casein genes in the different haplotypes. But here again, an analysis at the DNA level will probably be necessary to understand the mecanisms involved.

The 6 recognized $\alpha_{\mathrm{s1}}-\mathrm{Cn}$ alleles produce as many as 21 genotypic combinations. However, the differences between the rates of synthesis of the 4 allele groups are such that the distribution of the $\alpha_{\mathrm{s} 1}$-casein contents of milks shows a remarkable plurimodality. In addition, our results suggest a strong positive correlation between the $\alpha_{s 1}$-casein content and the casein content of milk. The superiority in casein contents of milks from animals possessing alleles associated with a high level of $\alpha_{s 1}$-casein, particularly the most frequent one, $\alpha_{\mathrm{s} 1}-\mathrm{Cn}^{\mathrm{A}}$, strongly favours the investigation and feasibility of a selection based on these alleles. However, a thorough analysis has still to be done, taking more particularly into account the expected effects of such a selection on the quantity and on the technological properties of milk. Because this selection would increase the proportion of individuals homozygous for $\alpha_{s 1}-\mathrm{Cn}^{\mathrm{A}}$ (which is presently as low as 1 to 2 p. 100), the properties of milk from such individuals should be carefully investigated.

BoulANGER et al. (1984) pointed out that the predominance in the populations of alleles associated with a decreased $\alpha_{\mathrm{s} 1}$-casein synthesis rate is difficult to explain. The existence of individuals possessing allele $\alpha_{\mathrm{s} 1}-\mathrm{Cn}^{\mathrm{A}}$ among males selected on progeny-test does not support the hypothesis of a close linkage between $\alpha_{\mathrm{s1}}-\mathrm{Cn}^{\mathrm{A}}$ and an unfavourable allele at another locus. Further investigations are needed to account for the exceptional situation found at the $\alpha_{\mathrm{s1}}-\mathrm{Cn}$ locus of the goat. 


\section{Acknowledgements}

We are much indebted for help, support or suggestions to J.C. LE JAouen, J.P. Sigwald, A. Maingot and G. De Montigny (ITOVIC), J. Bouillon (Station de Testage Caprin), G. Ricordeau, B. Mirman, P. Guillimin, J.C. Mercier, P. Gaye, L. Ollivier, P. Sellier, C. Felgines, Michèle BRIEnd (I.N.R.A.) and Stefania Dallolio (Bologna, Italy). We thank A. Ng KwAI HANG for revision of the manuscript and the anonymous referees for useful suggestions. This work was supported by a grant from I.N.R.A. (AIP 1985).

\section{References}

Boulanger A., Grosclaude F., Mahe M.F., 1984. Polymorphisme des caséines $\alpha_{\mathrm{s} 1}$ et $\alpha_{\mathrm{s} 2}$ de la chèvre (Capra hircus). Génét. Sél. Evol., 16, 157-176.

Ceppellini R., Siniscalco M., Smith C.A.B., 1956. The estimation of gene frequencies in a random mating population. Ann. Hum. Genet., 20, 97-115.

Grabar P., Williams C.A., 1953. Méthode permettant l'étude conjuguée des propriétés électrophorétiques et immunochimiques d'un mélange de protéines; applications au sérum sanguin. Biochim. Biophys. Acta, 10, 193-194.

Grosclaude F., Joudrier P., Mahé M.F., 1978. Polymorphisme de la caséine $\alpha_{\mathrm{s} 2}$ bovine : étroite liaison du locus $\alpha_{\mathrm{s} 2}-\mathrm{Cn}$ avec les loci $\alpha_{\mathrm{s} 1}-\mathrm{Cn}, \beta-\mathrm{Cn}$ et $\kappa-\mathrm{Cn}$; mise en évidence d'une délétion dans le variant $\alpha_{\mathrm{s} 2}-\mathrm{CnD}$. Ann. Génét. Sél. Anim., 10, 313-327.

LAEmmli U.K., 1970. Cleavage of structural proteins during the assembly of the head of bacteriophage T4. Nature, 227, 680-685.

LAURell C.B., 1966. Quantitative estimation of proteins by electrophoresis in agarose gel containing antibodies. Analyt. Biochem., 15, 45-52.

Mercier J.C., Maubois J.L., Poznanski S., Ribadeau-Dumas B., 1968. Fractionnement préparatif des caséines de vache et de brebis par chromatographie sur DEAE-cellulose, en milieu urée et 2-mercaptoéthanol. Bull. Soc. Chim. Biol., 50, 521-530.

OUCHTERLONY Ö, 1967. Immunodiffusion and immunoelectrophoresis. In: WeIR D.M. (ed.), Handbook of experimental immunology, 1, 655-706, Blackwell, Oxford and Edinburgh.

Thompson M.P., KIDDY C.A., 1964. Genetic polymorphism in caseins of cow's milk. III. Isolation and properties of $\alpha_{\mathrm{s} 1}$-caseins A, B and C. J. Dairy Sci., 47, 626-632.

Towbin H., Staehelin T., Gordon J., 1979. Electrophoretic transfer of proteins from polyacrylamide gels to nitrocellulose sheets : procedure and some applications. Proc. Natl. Acad. Sci., USA, 76, 4350-4354.

WEEKE B., 1976. General remarks on principles, equipment, reagents and procedures. In : AXELSEN N.H., Kroll J., and WeEKE B. (ed.), A manual of quantitative immunoelectrophoresis, 15-35, Universitetsforlaget, Oslo.

Wоүснік J.H., 1964. Polymorphism in к-casein of cow's milk. Biochem. Biophys. Res. Commun., 16, $267-271$.

Zitrle C.A., Custer J.J., 1963. Purification and some of the properties of $\alpha_{\mathrm{s}}$-casein and $k$-casein. J. Dairy Sci., 46, 1183-1188. 